\title{
APLIKASI TEORI PERMAINAN DALAM PENENTUAN STRATEGI PEMASARAN PROGRAM STUDI TEKNIK INFORMATIKA DAN TEKNIK INDUSTRI
}

\author{
Diyah Wijayati $^{1 \S}$, Edi Supriyadi ${ }^{2}$ \\ ${ }^{1}$ Prodi Teknik Informatika - Sekolah Tinggi Teknologi Bandung [Email: diyahwijayati@gmail.com] \\ ${ }^{2}$ Prodi Teknik Industri - Sekolah Tinggi Teknologi Bandung [Email: edipmatematika@gmail.com] \\ ${ }^{\S}$ Corresponding Author
}

\begin{abstract}
Competition in the world of education especially the highest level of education, is getting tougher in obtaining student. So that, needed to analyze the study program's marketing strategies in facing this competition. The aim of this research is making decision to determine the optimal strategy of the study program using game theory which is solved by the linear programming method. The data in this study obtained from the Informatics and Industrial Engineering study program at Sekolah Tinggi Teknologi Bandung. From application game theory, it is recommended that game with mixed strategy is an appropriate one. Result show that the optimal marketing strategy for Informatics Engineering study program is number of graduation strategy, tuition fee strategy, and number of lecturer strategy. While the optimal marketing strategy for Industrial Engineering study program is tuition fee strategy, popularity strategy, and number of graduation strategy.
\end{abstract}

Keywords: game theory, linear programming, mixed strategy, optimal

\section{PENDAHULUAN}

Perkembangan di dunia pendidikan yang cukup pesat menimbulkan persaingan dalam mendapatkan calon peserta didik. Fenomena ini tidak hanya terjadi di tingkat pendidikan dasar tetapi juga di tingkat pendidikan yang lebih tinggi seperti Perguruan Tinggi Swasta.

Ada dua acara memandang sebuah PTS yang pertama Perguruan Tinggi yang berprinsip nirlaba, kedua Perguruan Tinggi yang memenuhi Standar Nasional Pendidikan Tinggi (SNPT). Hal ini menimbulkan persaingan yang tinggi antar PTS dalam memperoleh calon mahasiswa sehingga dapat memenuhi peraturan yang ditetapkan UU Dikti.

Persaingan juga timbul antar program studi dalam satu PTS, hal ini berpengaruh pada penentuan jumlah kelas, jumlah kebutuhan dosen, ketersediaan ruangan dan lain sebagainya. Keputusan memilih program studi tergantung pada diri masing-masing calon mahasiswa. Oleh karena itu, untuk memenangkan kompetisi, pengetahuan tentang cara calon mahasiswa memilih program studi sangat penting untuk diketahui oleh PTS bersangkutan.
Masing-masing program studi saling berlomba untuk mengembangkan seluruh potensi dan kemampuannya guna menarik minat calon mahasiswa. Kemampuan bersaing tersebut sangat dipengaruhi oleh kinerja manajemen program studi bersangkutan dalam menentukan suatu strategi pemasaran yang tepat bagi masing-masing prodi. Dengan adanya situasi ini maka diperlukan pengaplikasian suatu teori yang bertujuan membantu pengambilan keputusan strategi pemasaran yang tepat sehingga dapat meningkatkan minat calon mahasiswa dan menghasilkan keuntungan yang optimal bagi program studi, yaitu teori permainan.

Teori permainan adalah studi tentang pengambilan keputusan di mana hasil bagi pembuat keputusan tidak hanya bergantung pada apa yang dilakukan pembuat keputusan tetapi juga pada keputusan pemain lain (Giordano, et. al. 2013: 378). Teori permainan digunakan untuk mencari strategi terbaik dalam suatu aktivitas, dimana setiap pemain di dalamnya sama-sama mencapai utilitas tertinggi. Keuntungan bagi yang satu 
merupakan kerugian bagi yang lain, maka dari itu digunakan asumsi bahwa setiap pemain mampu mengambil keputusan secara bebas dan rasional (Fatchiyah, 2011:2). Dalam teori permainan, para pemain memanfaatkan teknik mtematika dan pemikiran logis agar sampai pada kemungkinan strategi terbaik dalam pengambilan keputusan untuk memenangkan persaingan (Saifuddin, et.al., 2018:173). Tujuan dari penggunaan teori permainan ini adalah mengidentifikasi strategi yang optimal untuk setiap pemain (Simamora, 2013).

Teori permainan mempunyai unsur-unsur dasar dalam menyelesaikan suatu permainan, diantaranya adalah jumlah pemain, nilai perolehan/payoff dan strategi permainan (Fatchiyah, 2011). Permainan diklasifikasikan menurut jumlah kepentingan atau tujuan yang ada dalam permainan tersebut. Dalam hal ini perlu dipahami, bahwa pengertian jumlah pemain tidak selalu sama artinya jumlah orang yang terlibat dalam permainan. Jumlah pemain disini berarti jumlah kelompok pemain berdasarkan masing-masing kepentingan atau lebih, yang mempunyai kepentingan yang sama dapat diperhitungkan sebagai satu kelompok pemain. Nilai perolehan/payoff adalah hasil akhir yang terjadi pada akhir permainan berkenaan dengan ganjaran ini, permainan digolongkan menjadi dua macam kategori, yaitu permaina jumlah-nol (zero-sum games) dan permainan jumlah-bukan-nol (non-zerosum games). Strategi permainan dalam teori permainan adalah suatu siasat atau rencana tertentu dari seorang pemain sebagai reaksi atas aksi yang mungkin dilakukan oleh pemain yang menjadi saingannya, permainan diklasifikasikan menurut jumlah strategi yang tersedia bagi masing-masing pemain. Jika pemain baris memiliki $m$ kemungkinan strategi dan pemain kolom memiliki $n$ kemungkinan strategi, maka permainan tersebut dinamakan permainan $m \times n$. Strategi permainan optimal ada dua yaitu permainan strategi murni (pure strategy game) dan permainan strategi campuran (mixed strategy game). Permainan strategi murni adalah suatu permainan dengan posisi pilihan terbaik setiap pemain dicapai dengan memilih strategi tunggal. Jadi strategi murni adalah permainan di mana setiap pemain menggunakan satu strategi dengan probabilitas 1 sedang probabilitas strategi lain adalah nol (Ferguson, 2014). Sedang permainan strategi campuran adalah suatu permainan dengan pilihan strategi setiap pemain tidak tunggal.
Setiap permainan berhingga yang dianalisis dengan teori permainan selalu dapat disajikan dalam bentuk sebuah matriks permainan. Angka-angka dalam matriks permainan menunjukkan hasil-hasil dari strategi-strategi permainan yang berbeda-beda. Hasil-hasil ini dinyatakan dalam suatu bentuk ukuran efektifitas. Dalam permainan jumlah nol dua orang, bilangan-bilangan positif menunjukkan keuntungan bagi pemain baris dan kerugian bagi pemain kolom (Ferguson, 2014).

Teori permainan adalah model matematika bagi suatu situasi persaingan di mana penekanan dalam teori ini adalah pengambilan keputusan yang dilakukan oleh para pesaing dalam usahanya untuk menang sebesar mungkin (maksimasi kemenangan) atau kalah sekecil mungkin (minimasi kekalahan).

Sebuah perusahaan baik itu perusahaan jasa maupun industri lainnya akan menggunakan berbagai strategi dalam memasarkan produknya, hal ini dikarenakan kondisi persaingan saat ini sangat ketat. Jika sebuah perusahaan tidak menggunakan strategi yang tepat, maka perusahaan tersebut akan kalah dalam persaingan merebut pangsa pasar (Fadmawati, 2011: 34)

Sebagai badan hukum yang berprinsip nirlaba Sekolah Tinggi Teknologi Bandung berusaha meningkatkan jumlah mahasiswa pada setiap tahun ajaran baru. Di lain pihak sebagai perguruan tinggi, Sekolah Tinggi Teknologi Bandung juga diharapkan dapat memenuhi kriteria-kriteria penilaian dari Badan Akreditasi Nasional Perguruan Tinggi (BANPT). Hal ini menimbulkan konflik pada perguruan tinggi bersangkutan. Arti konflik di sini adalah menentukan strategi pemasaran yang tepat sehingga dapat meningkatkan jumlah calon mahasiswa dan juga memenuhi persyaratan minimum akreditasi.

Tujuan penelitian ini adalah: merumuskan model matematika setiap kemungkinan pemilihan strategi pemasaran Prodi Teknik Informatika dan Prodi Teknik Industri dalam menentukan strategi pemasaran yang optimal menggunakan teori permainan. Selanjutnya menyelesaikan teori permainan menggunakan metode pemrograman linier untuk memperoleh strategi pemasaran program studi yang optimal.

Jumlah pemain yang digunakan dalam penelitian ini ada dua yaitu Prodi Teknik Informatika sebagai pemain baris dan Prodi Teknik Industri sebagai pemain kolom.

Nilai perolehan atau payoff adalah sebutan 
untuk keuntungan yang diperoleh pemain. Keuntungan tidak hanya bisa berbentuk uang tapi bisa bentuk lain, seperti mendapat barang atau komoditas, kenaikan atau penurunan market share, atau mendapatkan jasa yang lebih baik. Dengan perkataan lain nilai perolehan adalah suatu bentuk ukuran efektivitas. Berkenaan dengan nilai perolehan ini, permainan digolongkan menjadi dua macam kategori, yaitu permainan jumlah-nol (zero-sum games) dan permainan jumlah-bukan-nol (nonzero-sum games). Permainan jumlah-nol terjadi jika jumlah perolehan dari seluruh pemain adalah nol, yaitu dengan memperhitungkan setiap keuntungan sebagai bilangan positif dan setiap kerugian sebagai bilangan negatif, selain dari itu adalah permainan jumlah-bukan-nol. Pada penelitian ini permainan yang digunakan adalah zero-sum games dengan ukuran efektivitas yang digunakan adalah rasio pertumbuhan.

Strategi permainan adalah rangkaian kegiatan atau rencana yang menyeluruh dari seorang pemain, sebagai reaksi atas aksi yang mungkin dilakukan oleh pemain lain yang menjadi pesaingnya. Dalam hal ini dianggap bahwa suatu strategi tidak dapat dirusak oleh para pesaing atau faktor lain. Dalam penelitian ini strategi pemasaran yang digunakan adalah strategi popularitas, strategi biaya kuliah, strategi jumlah kelulusan, dan strategi jumlah dosen.

Matriks permainan yaitu matriks yang semua unsur berupa nilai perolehan dari para pemain yang terlibat dalam permainan tersebut. Baris-barisnya menyatakan strategi-strategi yang dimiliki pemain pertama, sedangkan kolom-kolomnya menyatakan strategi-strategi yang dimiliki pemain kedua. Beberapa model teori permainan memerlukan fungsi utilitas. Fungsi utilitas memetakan utilitas dari sekumpulan barang dan jasa ke bilangan riil (Geckil, et.al., 2010: 13). Berikut ini fungsifungsi utilitas yang sering digunakan untuk membentuk matriks permainan:

$$
\begin{aligned}
& u\left(x_{1}, x_{2}\right)=x_{1} x_{2} \\
& u\left(x_{1}, x_{2}\right)=a x_{1}+b x_{2} \\
& u\left(x_{1}, x_{2}\right)=\max \left\{x_{1}, x_{2}\right\}
\end{aligned}
$$

Dalam peneltian ini untuk membentuk matriks permainan menggunakan dua fungsi perolehan yaitu:

$$
\begin{aligned}
& F(x, y)=c \times R \\
& G(x, y)=a x+b y
\end{aligned}
$$

dengan $a, b$, dan $c$ adalah bobot penilaian akreditasi, $R$ adalah rasio kenaikan dan $x$ dan $y$ adalah nilai dari masing-masing strategi yang dihitung menggunakan rumus perbandingan.

\section{METODE PENELITIAN}

Penelitian ini menggunakan data primer yang diperoleh dari database Sekolah Tinggi Teknologi Bandung. Pengolahan data pada penelitian ini dibantu dengan menggunakan perangkat lunak Microsoft Excel.

Langkah-langkah untuk menyelesaikan matriks permainan dapat direpresentasikan dalam bentuk diagram alir seperti yang tersaji pada Gambar 1

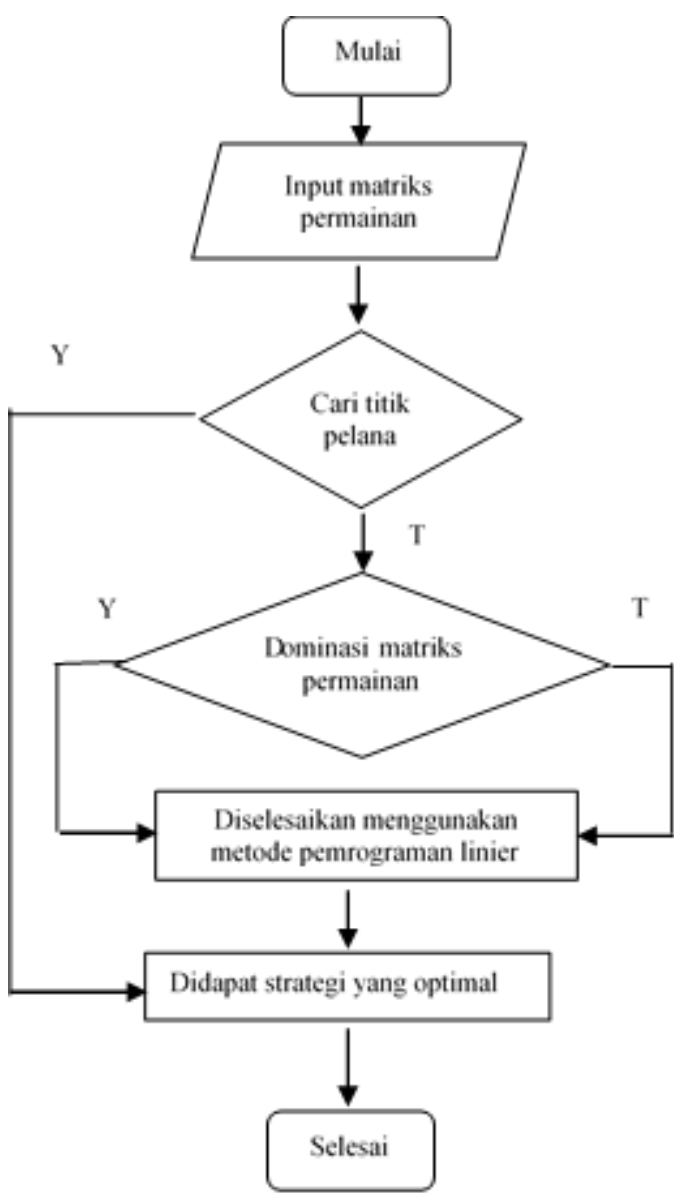

Gambar 1. Diagram Alir Penyelesaian Matriks Permainan

Penyelesaian matriks permainan yang berukuran lebih dari $2 \times 2$ dilakukan dominasi pada matriks permainan yaitu menghilangkan strategi-strategi yang tidak efektif. Untuk pemain baris, baris yang nilainya besar dapat mendominasi baris yang nilainya kecil sedang untuk pemain kolom, kolom yang nilainya kecil dapat mendominasi kolom yang nilainya besar. 
Aturan dominasi ini tidak mengubah nilai permainan dan strategi optimal masing-masing pihak, hanya mengurangi ukuran matriks permainan, sehingga matriks permainan dapat diselesaikan dengan metode pemrograman linier.

Untuk menentukan solusi masalah pemrograman linier digunakan algoritma kombinasi metode simpleks dan metode pivot dengan bantuan perangkat lunak SCILAB.

Algoritma berikut pada dasarnya adalah metode simpleks untuk menyelesaikan masalah dualitas secara simultan (Ferguson, 2014):

1. Jika elemen matriks permainan terdapat bilangan negatif maka tambahkan sebuah konstanta ke semua elemen untuk memastikan nilainya positif. (Jika hal ini dilakukan jangan lupa untuk mengurangi nilai yang diperoleh dengan konstanta semula untuk memperoleh nilai dari matriks yang asli).

2. Bentuk tabel matriks permainan berhingga yang diperbanyak seperti pada Tabel 1

Tabel 1. Matriks Permainan Diperbanyak

\begin{tabular}{|c|c|c|c|c|c|}
\hline & $y_{1}$ & $y_{2}$ & $\ldots$ & $y_{n}$ & \\
\hline$x_{1}$ & $a_{11}$ & $a_{12}$ & $\ldots$ & $a_{1 n}$ & 1 \\
\hline$x_{2}$ & $a_{21}$ & $a_{22}$ & $\ldots$ & $a_{2 n}$ & 1 \\
\hline$\vdots$ & $\vdots$ & $\vdots$ & & $\vdots$ & $\vdots$ \\
\hline$x_{m}$ & $a_{m 1}$ & $a_{m 2}$ & $\ldots$ & $a_{m n}$ & 1 \\
\hline \multicolumn{7}{|c|}{-1} & -1 & $\ldots$ & -1 & 0 \\
\hline dengan $m=$ & banyak strategi yang dimiliki \\
pemain baris \\
banyak strategi yang dimiliki \\
pemain kolom
\end{tabular}

3. Pilih elemen di dalam tabel sebagai pivot, misal elemen pivot adalah elemen pada baris $k$ dan kolom $l$, yang memenuhi: pertama angka pada baris paling bawah pada kolom pivot, $a(m+1, l)$ adalah negatif. Kedua pivot $a(k, l)$ sendiri harus positif. Ketiga Baris pivot, k, harus dipilih dari pembagian angka pada kolom paling kanan dengan pivot yang memberikan rasio paling kecil, $a(k, n+1) / a(k, l)$.

4. Lakukan aturan pivot seperti pada Gambar 2

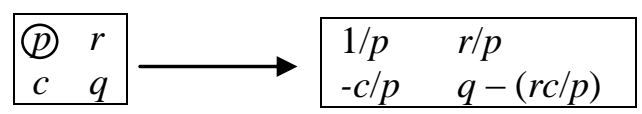

Gambar 2. Aturan Pivot

5. Tukar label di sebelah kiri baris pivot dengan label di sebelah atas pivot.
6. Jika masih terdapat bilangan negatif pada baris paling bawah ulangi langkah 3 .

7. Jika tidak terdapat bilangan negatif pada baris paling bawah diperoleh solusi pada tabel terakhir dengan aturan sebagai berikut: nilai permainan $v$ adalah kebalikan angka yang terletak di pojok kanan bawah tabel terakhir yang diperoleh. Strategi optimal untuk pemain baris disusun sebagai berikut jika variabel pemain baris berada di sebelah kiri maka probabilitas strategi ini adalah 0 . Jika variabelnya berada di sebelah atas maka probabilitas strategi diperoleh dengan membagi angka pada sisi bawah (baris paling bawah) kolom yang sama dengan variabel, dengan angka pada pojok kanan bawah. Sedang strategi optimal untuk pemain kolom disusun sebagai berikut jika variabel pemain kolom berada di sebelah atas maka probabilitas strategi ini adalah nol. Jika variabelnya berada di sebelah kiri maka probabilitas strategi diperoleh dengan membagi angka pada sisi kanan (kolom paling kanan) pada baris yang sama dengan variabel, dengan angka pada pojok kanan bawah.

\section{HASIL DAN PEMBAHASAN}

\subsection{Pengolahan Data dan Pembentukan Matriks Permainan}

Peneliti menggunakan fungsi perolehan pada persamaan (1) dan (2) yang diaplikasikan pada Tabel 2 dan Tabel 3 dan bobot yang digunakan yaitu bobot popularitas $=0,82$, bobot biaya kuliah $=0,41$, bobot kelulusan $=$ 1,23 , dan bobot dosen $=1,84$. Pada bagian ini hanya menyajikan beberapa contoh perhitungan untuk membentuk matriks permainan

Tabel 2. Jumlah Pendaftar, Jumlah Mahasiswa dan Jumlah Lulusan Tahun 2011-2017

\begin{tabular}{|c|c|c|c|c|c|c|}
\hline \multirow{2}{*}{$\begin{array}{c}\text { Tahun } \\
\text { Akademik }\end{array}$} & \multicolumn{2}{|c|}{$\begin{array}{l}\text { Jumlah } \\
\text { Pendaftar }\end{array}$} & \multicolumn{2}{|c|}{$\begin{array}{c}\text { Jumlah } \\
\text { Mahasiswa }\end{array}$} & \multicolumn{2}{|c|}{$\begin{array}{c}\text { Lulus } \\
\text { Tepat } \\
\text { Waktu } \\
\end{array}$} \\
\hline & TIF & TI & TIF & TI & TIF & $\mathrm{TI}$ \\
\hline 2011-2012 & 54 & 29 & 44 & 15 & 18 & 9 \\
\hline $2012-2013$ & 53 & 41 & 50 & 35 & 26 & 20 \\
\hline 2013-2014 & 63 & 59 & 47 & 44 & 15 & 27 \\
\hline 2014-2015 & 115 & 81 & 96 & 50 & & \\
\hline $2015-2016$ & 109 & 82 & 102 & 67 & & \\
\hline 2016-2017 & 168 & 111 & 107 & 69 & & \\
\hline
\end{tabular}


Tabel 3. Jumlah Dosen Tetap Sekolah Tinggi Teknologi Bandung

\begin{tabular}{cccc}
\hline \multirow{2}{*}{ Tahun } & \multicolumn{2}{c}{ Dosen Tetap } & \multirow{2}{*}{ Jumlah } \\
\cline { 2 - 3 } & TIF & TI & \\
\hline 2011 & 10 & 8 & 18 \\
\hline 2016 & 20 & 20 & 40 \\
\hline $\begin{array}{l}\text { Catatan : jumlah total dosen STTB } \\
\text { 60 orang }\end{array}$ & & ada \\
\hline
\end{tabular}

Contoh perhitungan untuk mengisi elemen elemen matriks permainan:

Rumus rasio popularitas:

$$
R=\frac{279-83}{83}=2,36
$$

Contoh perhitungan mengisi elemen dengan strategi yang digunakan sama:

$$
a_{11}=0,82 \times 2,36=1,935
$$

Contoh perhitungan mengisi elemen matriks dengan strategi yang digunakan berbeda:

Rumus nilai strategi:

$$
\begin{aligned}
& x_{1}=\frac{562}{965}=0,58 \\
& y_{2}=\frac{280}{726}=0,39
\end{aligned}
$$

Sehingga untuk elemen baris 1 kolom 2 dihitung sebagai berikut:

$$
a_{12}=(0,82 \times 0,58)+(0,41 \times 0,39)=0,636
$$

Dengan cara yang sama untuk menghitung

\begin{tabular}{|c|c|c|c|c|c|}
\hline \multirow{2}{*}{$\begin{array}{c}\text { Teknik } \\
\text { Informatik } \\
\mathrm{a}\end{array}$} & \multicolumn{4}{|c|}{ Teknik Industri } & \multirow[b]{2}{*}{ Min } \\
\hline & Y1 & Y2 & Y3 & Y4 & \\
\hline \multirow[t]{2}{*}{$\mathrm{X} 1$} & 1,93 & 0,63 & 1,07 & 1,08 & 0,63 \\
\hline & 5 & 6 & 8 & 3 & 6 \\
\hline \multirow[t]{2}{*}{$\mathrm{X} 2$} & 0,59 & 0,81 & 0,85 & 0,85 & 0,59 \\
\hline & 5 & 2 & 3 & 7 & 5 \\
\hline \multirow[t]{2}{*}{$\mathrm{X} 3$} & 0,97 & 0,78 & 0,68 & 1,23 & 0,68 \\
\hline & 2 & 7 & 9 & 5 & 9 \\
\hline \multirow[t]{2}{*}{$\mathrm{X} 4$} & 0,95 & 0,76 & 1,21 & 2,24 & 0,76 \\
\hline & 2 & 7 & 0 & 5 & 7 \\
\hline \multirow[t]{2}{*}{ Maks } & 1,93 & 0,81 & 1,21 & 2,24 & \\
\hline & 5 & 2 & 0 & 5 & \\
\hline
\end{tabular}
elemen-elemen yang lainnya maka bentuk dari matriks permainannya seperti yang tersaji pada Tabel 4

Tabel 4. Matriks Permainan
Berdasarkan Tabel 4, dapat dilihat bahwa nilai maksimum dari minimum baris $($ maksimin $)=0,767$ dan nilai minimum dari maksimum kolom (minimaks) $=0,812$, maka matriks permainan tidak mempunyai titik pelana.

Selanjutnya melakukan aturan dominasi pada Tabel 4 di atas diperoleh matriks permainan baru seperti yang tersaji pada Tabel 5.

Tabel 5. Matriks Permainan Hasil Dominasi

\begin{tabular}{ccccc}
\hline \multirow{2}{*}{ Teknik } & \multicolumn{3}{c}{ Teknik Industri } & \multirow{2}{*}{ Minimum } \\
\cline { 2 - 4 } Informatika & Y1 & Y2 & Y3 & \\
\hline $\mathrm{X} 1$ & 1,935 & 0,636 & 1,078 & 0,636 \\
\hline $\mathrm{X} 2$ & 0,595 & 0,812 & 0,853 & 0,595 \\
\hline $\mathrm{X} 3$ & 0,972 & 0,787 & 0,689 & 0,689 \\
\hline $\mathrm{X} 4$ & 0,952 & 0,767 & 1,210 & 0,767 \\
\hline Maksimum & 1,935 & 0,812 & 1,210 & \\
\hline
\end{tabular}

Pada Tabel 5 dapat dilihat bahwa matriks hasil dominasi tidak mempunyai titik pelana.

\subsection{Penyelesaian Matriks Permainan}

Model matematika untuk masalah pemrograman linier yang terbentuk adalah:

Pemain Teknik Informatika (pemain baris) (dual)

Minimumkan $\mathrm{w}=\mathrm{X} 1+\mathrm{X} 2+\mathrm{X} 3+\mathrm{X} 4$

Fungsi kendala:

$1,935 \mathrm{X} 1+0,595 \mathrm{X} 2+0,972 \mathrm{X} 3+0,952 \mathrm{X} 4>=1$

$0,636 \mathrm{X} 1+0,812 \mathrm{X} 2+0,787 \mathrm{X} 3+0,767 \mathrm{X} 4>=1$

$1,078 \mathrm{X} 1+0,853 \mathrm{X} 2+0,689 \mathrm{X} 3+1,210 \mathrm{X} 4>=1$

$\mathrm{X}(\mathrm{i})>=0$ untuk $\mathrm{i}=1, \ldots, 4$

Pemain Teknik Industri (pemain kolom) (primal)

Memaksimumkan $\mathrm{z}=\mathrm{Y} 1+\mathrm{Y} 2+\mathrm{Y} 3$

Fungsi kendala:

$1,935 \mathrm{Y} 1+0,636 \mathrm{Y} 2+1,078 \mathrm{Y} 3<=1$

$0,595 \mathrm{Y} 1+0,812 \mathrm{Y} 2+0,853 \mathrm{Y} 3<=1$

$0,972 \mathrm{Y} 1+0,787 \mathrm{Y} 2+0,689 \mathrm{Y} 3<=1$

$0,952 \mathrm{Y} 1+0,767 \mathrm{Y} 2+1,210 \mathrm{Y} 3<=1$

$\mathrm{Y}(\mathrm{i})>=0$ untuk $\mathrm{i}=1, \ldots, 3$

Menggunakan kombinasi metode simpleks dan metode pivot didapatkan hasil untuk Prodi Teknik Informatika nilai optimal yang diperoleh adalah $\mathrm{X} 1=0, \mathrm{X} 2=0,5772353, \mathrm{X} 3$ $=0,5981769$, dan $\mathrm{X} 4=0,0789045$ dengan nilai optimum persamaannya adalah 1,2543167. Sedang untuk Prodi Teknik Industri nilai optimal yang diperoleh adalah Y1 $=0,0940383$, $\mathrm{Y} 2=1,1139081$, dan $\mathrm{Y} 3=0,0463703$. 
Dari hasil perhitungan maka nilai permainan $v=1 / 1,2543167=0,79725$ dan probabilitas strategi optimal untuk program studi Teknik Informatika adalah:

$$
\begin{aligned}
& p_{1}=\frac{0}{1,2543167}=0 \\
& p_{2}=\frac{0,5772353}{1,2543167}=0,4602 \\
& p_{3}=\frac{0,5981769}{1,2543167}=0,47689 \\
& p_{4}=\frac{0,0789045}{1,2543167}=0,06291
\end{aligned}
$$

Sedang strategi optimal untuk program studi Teknik Industri adalah:

$$
\begin{aligned}
& q_{1}=\frac{0,0940383}{1,2543167}=0,07497 \\
& q_{2}=\frac{1,1139081}{1,2543167}=0,88806 \\
& q_{3}=\frac{0,0463703}{1,2543167}=0,03697
\end{aligned}
$$

Interpretasi dari hasil adalah bila program ingin memaksimumkan kemenangan atau menaikkan keuntungan maka strategi yang diprioritaskan adalah X3 (strategi jumlah kelulusan) yang memiliki probabilitas $47,689 \%$ lalu strategi X2 (strategi biaya kuliah) yang memiliki probabilitas sebesar $46,02 \%$ dan yang terakhir strategi X4 (strategi jumlah dosen) dengan nilai probabilitas sebesar 6,291\%, sedang untuk program studi Teknik Industri bila ingin meminimumkan kekalahan atau menurunkan kerugian maka strategi yang diprioritaskan adalah strategi Y2 (strategi biaya kuliah) yang memiliki probabilitas sebesar $88,806 \%$ lalu strategi Y1 (strategi popularitas) yang memiliki probabilitas sebesar 7,497\% dan terakhir Y3 (strategi jumlah kelulusan) dengan nilai probabilitas sebesar 3,697\%.

\section{KESIMPULAN DAN SARAN}

\subsection{Kesimpulan}

Berdasarkan hasil perhitungan sebaiknya program studi Teknik Informatika dan Teknik Industri menggunakan permainan strategi campuran di mana strategi pemasaran optimal program studi Teknik Informatika adalah strategi jumlah kelulusan (X3), strategi biaya kuliah (X2), dan strategi jumlah dosen (X4) karena dapat menaikkan keuntungan dari 0,767 menjadi 0,79725 .

Sedangkan strategi optimal program studi Teknik Industri adalah strategi biaya kuliah (Y2), strategi popularitas (Y1), dan strategi jumlah kelulusan (Y3) karena dapat mengurangi kerugian dari 0,812 menjadi 0,79725 .

\subsection{Saran}

Dalam matriks penilaian borang akreditasi program studi sarjana terdapat lebih dari lima puluh aspek yang dapat dijadikan pilihan strategi. Selain itu banyak perguruan tinggi swasta yang memiliki lebih dari dua program studi, sehingga masing-masing dapat dijadikan sebagai pemain. Bagi yang akan melanjutkan pembahasan penerapan teori permainan di bidang pendidikan disarankan melakukan survei sehingga data yang diperoleh lebih akurat.

\section{DAFTAR PUSTAKA}

Geckil, I.K. and Anderson, P.L.2010. Applied Game Theory An Strategic Behvior, Taylor and Francis Group, LLC.

Fatchiyah, N. 2011. Aplikasi Matriks dalam Teori Permainan untuk Menentukan Strategi Pemasaran. Skripsi. Malang: Universitas Islam Negeri Maulana Malik.

Fadmawati, K.D. 2011.Reformulasi Strategi Pemasaran untuk Meningkatkan Occupancy Room Rate di Hotel Four Seasons Resort Jimbaran Bali. Tesis. Denpasar: Universitas Udayana.

Giordano, F. R., Fox, W. P., and Horton, S. B. 2013. A First Course In Mathematical Modelling. Fifth Edition. Cengage Learning, pp. $378-457$.

Simamora, C.H., Rosmaini, E., dan Napitupulu, N. 2013. Penerapan Teori Permainan dalam Strategi Pemasaran Produk Ban Sepeda Motor di FMIPA USU. Jurnal Saintia Matematika. 1(2), pp. 129 - 137.

Ferguson, T.S. 2014. Game Theory. Edisi kedua. Bagian II. Mathematic Departemen UCLA

Saifuddin, A., Tastrawati, N.K.T., dan Sari, K. 2018. Penerapan Konsep Teori Permainan (Game Theory) dalam Pemilihan Strategi Kampanye Politik. E-Jurnal Matematika. 7(2), pp. $173-179$. 